PRACE NAUKOWE UNIWERSYTETU EKONOMICZNEGO WE WROCLAWIU

\title{
Malgorzata Kutera
}

Uniwersytet Jagielloński

e-mail: malgorzata.kutera@uj.edu.pl

\section{NOWY RAPORT BIEGLEGO REWIDENTA - IMPLEMENTACJA PRZY AUDYCIE SPÓEEK WIG-20}

\section{NEW STATUTORY AUDITOR REPORT - IMPLEMENTATION IN AUDITS OF WIG-20 COMPANIES}

DOI: $10.15611 / \mathrm{pn} .2018 .503 .25$

JEL Classification: M41, M42, G32

Streszczenie: Celem artykułu jest prezentacja istotnych zmian w sposobie raportowania przez biegłego rewidenta wyników audytu do inwestorów oraz analiza stopnia ich implementacji przy badaniu sprawozdań finansowych spółek zaliczanych do WIG-20. Wydawana do tej pory, dość sztywna w brzmieniu opinia wraz z raportem nie spełnia już oczekiwań środowiska biznesowego. Główna teza brzmi: nowa struktura raportu biegłego rewidenta pokazuje istotne elementy metodologii badania sprawozdania i dzięki temu ułatwia czytelnikom zrozumienie wyników audytu. Artykuł opiera się na analizie zmian legislacyjnych w tym zakresie oraz opinii z badania skonsolidowanych sprawozdań finansowych największych spółek notowanych na warszawskiej GPW. Opracowanie prezentuje kluczowe zagadnienia związane ze zmianą międzynarodowych i krajowych przepisów prawnych dotyczących raportów przygotowywanych przez biegłych rewidentów oraz ich praktyczną implementacją przez spółki audytorskie. Wyniki badań wskazują, że część biegłych rewidentów na bieżąco wdraża nowe elementy raportowania.

Słowa kluczowe: opinia biegłego rewidenta, rewizja finansowa, spółki giełdowe, międzynarodowe standardy badania.

Summary: The purpose of this article is to present significant changes in the way in which a statutory auditor reports audit results to shareholders and to analyse the extent to which they have been implemented in financial audits of companies included in the WIG-20. The opinion with report issued previously, of a rather inflexible wording, no longer meets the expectations of the business community. The main thesis is that the new structure of the statutory auditor's report shows significant elements of the methodology of financial statement auditing and thus helps the reader understand audit results. This article is based on an analysis of legislative changes in this regard and the opinions from audits of consolidated financial statements of the largest companies listed on the Warsaw Stock Exchange. The publication presents key issues connected with the change of international and Polish legal regulations governing reports executed by statutory auditors and their practical implementation by audit firms. The results of research indicate that some statutory auditors are currently implementing new elements of reporting.

Keywords: statutory auditor opinion, financial audit, listed companies, international auditing standards. 


\section{Wstęp}

System rewizji finansowej przechodzi obecnie gruntowne zmiany zarówno w skali ogólnoświatowej, jak i krajowej. Dotyczą one nie tylko kwestii formalnych i organizacyjnych związanych z wykonywaniem zawodu biegłego rewidenta, ale również spraw dotyczących szerszego propagowania istoty audytu w środowisku biznesowym. W tym kontekście szczególne znaczenie mają wytyczne dotyczące sposobu komunikowania przez audytora wyników swojej pracy. Praktyka pokazuje, że dotychczasowa forma opinii wydawanej przez biegłego rewidenta nie spełnia już swojej roli. Zmieniło się zapotrzebowanie informacyjne czytelników sprawozdań finansowych, którzy chcą mieć możliwość poznania szerszego kontekstu pracy audytorów w celu efektywniejszej analizy wniosków ujętych w opiniach.

Mając na uwadze oczekiwania inwestorów, opracowano nowy model raportowania przez biegłych rewidentów. Jego największą zmianą jest konieczność przedstawienia kluczowych zagadnień badania oraz zastosowanych procedur weryfikacyjnych. W skali ogólnoświatowej nowe wytyczne zostały zawarte w International Standards on Auditing. Konkretne rozwiązania wdrożono też na poziomie Unii Europejskiej.

Celem niniejszego artykułu jest prezentacja głównych zmian w systemie raportowania biegłego rewidenta oraz stopnia ich implementacji przy audycie sprawozdań finansowych spółek zaliczanych do WIG-20. Wstępna analiza opinii z badania sprawozdań tych podmiotów wskazuje, że na polskim rynku część audytorów już wcześniej fakultatywnie wprowadzała pewne zmiany w treści opinii, śledząc na bieżąco proponowane zmiany legislacyjne. Rozważania oparto na przekonaniu, że nowa struktura raportu biegłego rewidenta pokazuje istotne elementy metodologii badania sprawozdania i dzięki temu ułatwia czytelnikom zrozumienie wyników audytu.

Dla zweryfikowania powyższej tezy dokonano szczegółowej analizy opinii z badania skonsolidowanych sprawozdań finansowych dla spółek WIG-20 za lata 2013-2016, zidentyfikowano wzorcowy raport audytora przygotowany w pełni zgodnie z nowymi wymogami i zaprezentowano jego kluczowe elementy.

\section{Legislacyjne aspekty zmian $w$ raportowaniu biegłego rewidenta}

Pierwsze prace nad zmianą raportu biegłego rewidenta na szczeblu ogólnoświatowym zaczęły się już w 2006 r. od szerokich konsultacji prowadzonych przez Radę Międzynarodowych Standardów Rewizji Finansowej i Usług Atestacyjnych (IA$A S B)$ w zakresie oceny użyteczności opinii audytorów. Kontynuowane przez kolejne lata badania poskutkowały szeroką nowelizacją międzynarodowych standardów rewizji finansowej (ISA). W styczniu 2015 r. zostały opublikowane zmiany standardów, które zaczęły obowiązywać dla audytów sprawozdań finansowych kończących 
się 15 grudnia 2016 r. lub później. W sumie znowelizowano pięć standardów: ISA 700 Forming an Opinion and Reporting on Financial Statements, ISA 705 Modifications to the Opinion in the Independent Auditor's Report, ISA 706 Emphasis of Matter Paragraphs and Other Matter Paragraphs in the Independent Auditor's Report, ISA 570 Going Concern, ISA 260 Communication with Those Charged with Governance. Oprócz tego wprowadzono jeden nowy standard ISA 701 Communicating Key Audit Matters in the Independent Auditor's Report, który jest najważniejszy w kontekście omawianych zmian.

Podobne działania zostały podjęte na poziomie UE. Nowe wytyczne w zakresie raportowania biegłego przedstawiono w dyrektywie Parlamentu Europejskiego i Rady nr 2014/56/UE z dnia 16.04.2014 r. [art. 28] oraz rozporządzeniu Parlamentu Europejskiego i Rady nr 537/2014 z dnia 16.04.2014 r. [art. 10]. Zgodnie z tymi aktami nowe zasady raportowania obowiązują do audytów sprawozdań finansowych zaczynających się 17 czerwca 2016 r. lub później, czyli efektywnie będą one dotyczyć rocznych sprawozdań kończących się najwcześniej 30 czerwca 2017 r.

W kontekście legislacji krajowej należy zwrócić uwagę, że obecnie w Polsce obowiązują stare zasady raportowania biegłego rewidenta. Co prawda na podstawie uchwały nr 2783/52/2015 Krajowej Rady Biegłych Rewidentów z dnia 10 lutego 2015 r. wdrożono stosowanie międzynarodowych standardów badania, ale dotyczyło to ich wcześniejszego brzmienia. Przyjęcie znowelizowanej wersji międzynarodowych standardów jest zatem konieczne.

Należy dodać, że międzynarodowe regulacje dopuszczają możliwość wcześniejszego fakultatywnego wdrożenia zmienionych zasad raportowania przez audytora. Analiza zaprezentowana poniżej wskazuje, że takie przypadki dotyczą również polskiego rynku.

\section{Struktura nowego raportu audytora}

Znowelizowane standardy międzynarodowe wprowadzają szereg istotnych zmian $\mathrm{w}$ przygotowywaniu raportu $\mathrm{z}$ badania sprawozdania finansowego. Podstawowe zagadnienia związane $\mathrm{z}$ minimalnym zakresem i układem informacji zawartych w nowej opinii biegłego rewidenta zostały ujęte w ISA 700 Forming an Opinion and Reporting on Financial Statements. Zmiany dotyczą również obszarów przedstawionych $\mathrm{w}$ innych standardach związanych m.in. z kontynuowaniem działalności przez podmiot badany, modyfikacją opinii w zależności od jej rodzaju, komunikowaniem się z organami nadzoru i wreszcie ujawnianiem kluczowych kwestii badania [IAASB, March 2015]. Nowa struktura raportu została przedstawiona w tabeli 1.

Powyższe wymagania dotyczące budowy raportu $z$ badania sprawozdania finansowego ujęte w standardach międzynarodowych zostały w niektórych aspektach wyraźnie rozszerzone na poziomie Unii Europejskiej. W odniesieniu do badania 
Tabela 1. Obligatoryjna struktura nowego raportu biegłego rewidenta zgodna z International Standards on Auditing

\section{Tytul:}

Powinien zawierać wyraźne wskazanie, że opinia jest wydawana przez niezależnego audytora

Adresaci:

Głównymi adresatami opinii z badania sprawozdania finansowego są właściciele podmiotów audytowanych

\section{Opinia:}

Jest to pierwsza sekcja merytoryczna i powinna mieć wyodrębniony wyraźnie nagłówek „opinia”. Należy w niej zawrzeć:

- informacje o badanym podmiocie gospodarczym,

- stwierdzenie, że sprawozdanie zostało przez biegłego zbadane,

- identyfikację wszystkich elementów rocznego sprawozdania, które podlegały audytowi (łącznie z notami objaśniającymi, zawierającymi również opis podstawowych zasad rachunkowości),

- okres obrachunkowy dotyczący badanego sprawozdania,

- stwierdzenie, czy sprawozdanie przedstawia wiarygodne dane we wszystkich istotnych aspektach

\section{Podstawa opinii:}

Kolejna merytoryczna część raportu, która powinna mieć wyraźny nagłówek o powyższym brzmieniu.

W tej sekcji należy ujać:

- stwierdzenie, że badanie sprawozdania zostało przeprowadzone zgodnie z International Standards on Auditing,

- wspomnienie o zakresie odpowiedzialności biegłego rewidenta, która jest wyraźnie określona w kolejnej części raportu,

- zaznaczenie pełnej niezależności biegłego rewidenta zarówno w rozumieniu podstawowych aktów prawnych regulujących wykonywanie zawodu w danym kraju, jak również w kontekście obowiązujących kodeksów etyki (szczególnie Code of Ethics for Professional Accountants wydany przez IESBA),

- stwierdzenie, że na podstawie zebranych w czasie audytu dowodów biegły ma podstawę do wyrażenia opinii

\section{Kontynuacja dzialania:}

Audytor powinien zweryfikować możliwość kontynuowania działalności przez badany podmiot. W zakresie ujawniania w raporcie informacji na ten temat należy kierować się postanowieniami ISA 570.

\section{Kluczowe zagadnienia badania:}

W tym segmencie opinii należy stosować zasady nowego ISA 701 Communicating Key Audit Matters in the Independent Auditor's Report. Chodzi

o przedstawienie tych zagadnień, na które audytor zwrócił szczególną uwagę podczas badania sprawozdania. W szczególności należy tu zawrzeć opis:

- obszarów o najwyższym oszacowanym ryzyku istotnego zniekształcenia czy innych znaczących ryzykach zidentyfikowanych podczas audytu,

- znaczących osądów biegłego rewidenta w stosunku do tych obszarów sprawozdania, które opierają się na niepewnych szacunkach,

- efektów badania znaczących zdarzeń i transakcji, które miały miejsce w badanym okresie

\section{Odpowiedzialność za sprawozdanie finansowe:}

Kolejna merytoryczna część raportu, która powinna mieć wyraźny nagłówek o powyższym brzmieniu. Wskazuje wyraźnie, który organ ponosi odpowiedzialność za prawidłowe sporządzenie sprawozdania finansowego. W większości przypadków chodzi tutaj o zarząd. W tej sekcji audytor musi wskazać na odpowiedzialność zarządu głównie w dwóch aspektach: 
- przygotowanie sprawozdania finansowego zgodnie z zasadami rachunkowości oraz prawidłowe funkcjonowanie kontroli wewnętrznej zapewniającej, że sprawozdanie nie zawiera istotnych nieprawidłowości spowodowanych błędem czy też celowym nadużyciem,

- właściwe określenie możliwości kontynowania działalności przez badaną jednostkę.

Oprócz tego należy wyraźnie przedstawić zakres odpowiedzialności organów nadzoru (rady nadzorczej) nad procesem sprawozdawczości finansowej przedsiębiorstwa

\section{Odpowiedzialność audytora za badanie sprawozdania finansowego:}

Podobnie jak w poprzednich sekcjach należy wyodrębnić taki nagłówek. Zakres informacji tej części opinii został mocno poszerzony. Jako podstawę w każdym przypadku należy tutaj zamieścić informacje, że:

- celem audytu jest uzyskanie uzasadnionej pewności, że sprawozdanie finansowe jako całość nie zawiera istotnych nieprawidłowości spowodowanych błędem lub oszustwem,

- uzasadniona pewność oznacza, że jest to wysoki stopień pewności. Nie gwarantuje ona jednak, że każda istotna nieprawidłowość zostanie wykryta,

- nieprawidłowości są istotne wówczas, gdy można stwierdzić, że mają one realny wpływ na decyzje podejmowane przez czytelników sprawozdania finansowego.

Poza wymienionymi kwestiami należy zawrzeć również dodatkowe zagadnienia przedstawiające istotę badania sprawozdania finansowego. Ten rozszerzony opis nie musi być ujęty w raporcie biegłego rewidenta. Można go np. umieścić w załączniku do raportu. Dotyczy następujących kwestii:

- oświadczenia, że przy audycie identyfikuje i mierzy się ryzyko istotnego zniekształcenia wywołane zarówno błędem, jak i oszustwem oraz stosuje odpowiednie procedury z tym związane. Należy też wskazać, iż ryzyko niewykrycia zniekształcenia wywołane oszustwem jest wyższe,

- wskazania, że biegły zapoznał się z systemem kontroli wewnętrznej, ale tylko w takim zakresie, który pomaga mu zaprojektować właściwe procedury audytu. Nie jest celem biegłego wydanie opinii o efektywności tego systemu,

- oceny poprawności zastosowanych zasad rachunkowości oraz racjonalności szacunków ujętych w sprawozdaniu,

- oceny racjonalności przyjętego przez zarząd założenia kontynuowania działalności gospodarczej

\section{Pozostała odpowiedzialność biegłego w stosunku do sprawozdawczości spółki:}

Jeżeli zgodnie z przepisami prawa obowiązującymi w danym kraju audytor ma określony dodatkowy zakres odpowiedzialności wykraczający poza granice International Standards on Auditing, należy w raporcie wyodrębnić dodatkową sekcję „Raport o pozostałych wymaganiach prawnych i regulacyjnych”. Chodzi tutaj głównie o czytelne wydzielenie zakresu odpowiedzialności przewidzianego standardami audytu i innymi przepisami prawa

\section{Wskazanie biegłego rewidenta przeprowadzającego badanie w imieniu firmy audytorskiej oraz podpisy:}

Należy wskazać firmę audytorską oraz biegłego odpowiedzialnego za audyt. Podpis biegłego rewidenta, który może być złożony również w imieniu firmy audytorskiej. Oprócz podpisu biegłego rewidenta wykonującego badanie może być też dodatkowy podpis innej osoby reprezentującej firmę audytorską

\section{Adres firmy audytorskiej i data sporządzenia raportu:}

Data sporządzenia raportu nie może być wcześniejsza niż data sporządzenia sprawozdania finansowego przez jednostkę badaną oraz data złożenia stosownego oświadczenia przez zarząd

Źródło: opracowanie własne na podstawie ISA 700 Forming an Opinion and Reporting on Financial Statements oraz IAASB, New and Revised Auditor Reporting Standards and Related Conforming Amendments, January 2015. 
sprawozdań JZP wprowadzono dodatkowe obligatoryjne informacje, które powinny być w nim zawarte [Rozporządzenie nr 537/2014, art. 10]:

a) stwierdzenie, kto lub który organ powołał biegłego rewidenta lub firmę audytorską,

b) wskazanie daty powołania oraz całkowitego nieprzerwanego okresu trwania zlecenia, w tym także przypadki przedłużenia zlecenia w przeszłości oraz ponownego powołania biegłych rewidentów lub firm audytorskich,

c) rozszerzenie zagadnień związanych z ryzykiem i reakcją biegłego:

- opis najbardziej znaczących rodzajów ryzyka istotnego zniekształcenia, w tym ryzyka spowodowanego oszustwem,

- podsumowanie reakcji biegłego rewidenta na te ryzyka,

- najważniejsze spostrzeżenia związane z tymi problemami,

d) wyjaśnienie, w jakim zakresie badanie ustawowe uznano za umożliwiające wykrycie nieprawidłowości, w tym oszustw,

e) potwierdzenie, że opinia z badania jest spójna z dodatkowym sprawozdaniem, które audytorzy są zobligowani do sporządzania dla potrzeb komitetu audytu,

f) oświadczenie, że nie były świadczone usługi niebędące badaniem zabronione przez prawo oraz biegły rewident lub firma audytorska pozostali niezależni od badanej jednostki, w trakcie przeprowadzania badania,

g) wskazanie wszelkich usług, poza badaniem ustawowym, które świadczył biegły rewident lub firma audytorska na rzecz badanej jednostki lub jednostek przez nią kontrolowanych i które nie zostały ujawnione w sprawozdaniu z działalności lub w sprawozdaniu finansowym.

Dokładna analiza porównawcza obu regulacji wskazuje jednak również, że niektóre obszary dotyczące raportu $\mathrm{z}$ audytu zawarte w unijnych przepisach są węższe niż przedstawione w International Standards on Auditing. Szczególnie chodzi tutaj o opis kluczowych zagadnień badania. W rozporządzeniu UE zostały one właściwie zawężone wyłącznie do rozszerzonego opisu ryzyka. W ISA 700 wyraźnie wskazuje się jeszcze na przedstawienie znaczących osądów biegłego rewidenta w stosunku do tych obszarów sprawozdania, które opierają się na niepewnych szacunkach, oraz efektów badania znaczących zdarzeń i transakcji, które miały miejsce w badanym okresie. Można tutaj oczywiście domniemywać, że istotne i niepewne szacunki ujęte w sprawozdaniu finansowym powinny być traktowane jako element ryzyka, a więc ujawnione również w raporcie biegłego przygotowanym zgodnie z unijnymi wytycznymi. Dyrektywa i rozporządzenie UE nie wymagają również tak szerokiego przedstawiania zakresu odpowiedzialności audytora.

W tym kontekście warto zaznaczyć, że regulacje unijne pozwalają państwom członkowskim na ustalenie dodatkowych wymogów dotyczących zawartości raportu z badania sprawozdania finansowego. 


\section{Ogólna analiza opinii z audytu spółek należących do WIG-20 za lata 2013-2016}

W celu weryfikacji stopnia implementacji i przygotowania do wdrożenia nowej struktury raportu biegłego rewidenta dokonano analizy opinii wydanych przez audytorów dla sprawozdań skonsolidowanych spółek WIG-20 z ostatnich kilku lat. Stwierdzono, że część audytorów już wdrożyła opis nowych kwestii ujętych w przedstawionych zmianach regulacyjnych. W jednym przypadku został wydany raport w całości zbieżny z nowymi wymogami International Standards on Auditing. Podsumowanie próby badawczej zostało przedstawione w tabeli $2^{1}$.

Tabela 2. Dodatkowe elementy opisowe zawarte w opiniach z badania skonsolidowanych sprawozdań finansowych spółek WIG-20

\begin{tabular}{|l|l|c|}
\hline \multicolumn{1}{|c|}{ Opinie dla SF za 2016 r. } & \multicolumn{1}{|c|}{ Opinie dla SF za 2015 r. } & Opinie dla SF za 2014 r. \\
\hline 1. Orange Polska SA - EY & 1.PGE Polska Grupa & 1. PGE Polska Grupa \\
2. PGE Polska Grupa & Energetyczna SA - KPMG & Energetyczna SA - KPMG \\
$\begin{array}{l}\text { Energetyczna SA - KPMG } \\
\begin{array}{l}\text { 3. PKN Orlen SA - KPMG } \\
\text { 4. Cyfrowy Polsat SA - PwC }\end{array}\end{array}$ & 2. PKN Orlen SA - KPMG \\
\hline
\end{tabular}

Źródło: opracowanie własne.

Analiza opinii wskazała, że pierwsze rozbudowane opisy nowych kwestii pojawiły się już w raportach z badania sprawozdań finansowych za 2014 r. Dotyczyło to dwóch spółek obsługiwanych przez tego samego audytora - KPMG. Taka sama sytuacja powtórzyła się przy badaniu sprawozdań finansowych za 2015 r. W szczególności chodziło tutaj o prezentację kluczowych zagadnień badania i opis stosowanych procedur. Z kolei przy audytach za 2016 r. zidentyfikowano już cztery przypadki rozszerzonych zapisów w opinii, przy czym $\mathrm{w}$ jednym $\mathrm{z}$ nich był dokument w pełni zgodny z nowymi wytycznymi zawartymi w International Standards on Auditing. Ten wzorcowy przypadek dotyczy badania skonsolidowanego sprawozdania finansowego za 2016 r. dla Cyfrowego Polsatu SA wykonanego przez PwC. Należy jednak zwrócić uwagę, że audytor wybrał pośrednie rozwiązanie - przygotował trzy oficjalne dokumenty zawierające podsumowanie wyników audytu: opinię z badania sprawozdania według starych zasad, raport będący uzupełnieniem powyższej opinii według starych zasad oraz dodatkowo nowe sprawozdanie z badania przygotowane wg ISA 700 Forming an Opinion and Reporting on Financial Statements.

\footnotetext{
${ }^{1}$ Należy zaznaczyć, że na dzień zakończenia analizy danych dwie spółki z WIG-20 nie miały jeszcze opublikowanej opinii z badania skonsolidowanego sprawozdania finansowego za $2016 \mathrm{r}$.
} 
Podsumowanie zawarte w tabeli 2 wyraźnie pokazuje również, że największe doświadczenie $\mathrm{w}$ dodatkowych opisach zawartych w opiniach biegłych rewidentów ma KPMG, które jako pierwsze wprowadziło te elementy na polskim rynku. Na razie są to tylko rozwiązania pośrednie, tzn. do standardowej opinii wprowadzane są pewne elementy ujęte $\mathrm{w}$ znowelizowanych regulacjach i dodatkowo jest przygotowywany oddzielny raport $\mathrm{w}$ klasycznym dotychczasowym ujęciu. Warto przypomnieć, że zgodnie z międzynarodowymi i europejskimi regulacjami obowiązuje wyłącznie jeden dokument.

Na koniec wstępnej oceny należy również dodać, że żaden $\mathrm{z}$ audytorów nie pokusił się o przygotowanie sprawozdania $\mathrm{z}$ badania $\mathrm{w}$ wersji zgodnej ze znowelizowanymi regulacjami unijnymi.

\section{Wzorcowy raport biegłego rewidenta przygotowany zgodnie z nowelizacją International Standards on Auditing - Cyfrowy Polsat SA}

\subsection{Wprowadzenie}

Jak wspomniano powyżej, pierwszy raport $\mathrm{z}$ badania skonsolidowanego sprawozdania finansowego $\mathrm{w}$ pełni zgodny ze znowelizowanymi przepisami międzynarodowych standardów rewizji finansowej został przygotowany przez $\mathrm{PwC}$ dla sprawozdania za 2016 r. spółki Cyfrowy Polsat SA. Dokonano szczegółowej analizy treści w nim zawartych i stwierdzono, że spełnia wszystkie wymagania ujęte w tabeli 1. Spośród nich największą uwagę warto zwrócić na kluczowe zagadnienia badania, które są zupełną nowością w dotychczasowej praktyce audytorskiej. W przypadku omawianego raportu ten nowy zakres merytoryczny został podzielony na dwie sekcje:

- „nasze podejście do badania” oraz

- „kluczowe kwestie badania”.

W ramach opisu podejścia do badania audytor zidentyfikował trzy podstawowe obszary, które chciał zakomunikować czytelnikom sprawozdania: istotność, zakres badania grupy oraz kluczowe kwestie badania. Każdy z tych trzech elementów został szczegółowo omówiony w raporcie.

\subsection{Istotność i zakres audytu}

Przedstawienie poziomu istotności rozpoczęto od wyraźnego wskazania, że ma on bezpośredni wpływ na zakres przeprowadzonego badania i określa wielkość dopuszczalnego zniekształcenia. Zaprezentowano kwotowo poziom przyjętej istotności 
ogólnej - 91 mln zł oraz podstawę jego ustalenia - 2,5\% wskaźnika EBITDA. Zawarto również szerokie uzasadnienie przyjętej podstawy wyliczenia - zdaniem audytora wskaźnik ten jest ogólnie przyjętym punktem odniesienia, w szczególności dla jednostek o istotnych kosztach finansowania zewnętrznego i amortyzacji. Na koniec wspomniano, że zgodnie z ustaleniami poczynionymi z komitetem audytu badanego podmiotu zaraportowane zostaną wszystkie zniekształcenia o wartości większej niż 4,5 mln zł.

Audytor zaznaczył, że przy określaniu zakresu badania wziął pod uwagę geograficzną i zarządczą strukturę grupy kapitałowej, procesy księgowe, kontrole oraz branżę, w której podmiot działa. Wyraźnie określono, które podmioty tworzące grupę zostały zweryfikowane bezpośrednio przez własnych audytorów, a w jakich przypadkach polegano na pracy innych biegłych rewidentów. Zaznaczono również, iż zespół przeprowadzający badanie wizytował wybrane spółki zależne, nawet jeśli nie audy tował ich sprawozdań finansowych. Ostatecznie podsumowano, że zakres badania pokrył $94 \%$ przychodów grupy oraz $76 \%$ wartości jej wyniku finansowego (przed korektami konsolidacyjnymi).

\subsection{Kluczowe kwestie badania}

Na początku tej sekcji raportu wspomniano, że kluczowe kwestie są to według zawodowego osądu audytora zagadnienia najbardziej znaczące podczas badania sprawozdania jako całości. W dalszej części, przy opisie poszczególnych problemów, zachowano następujący schemat: przedstawienie kluczowej kwestii, uzasadnienie jej wyboru, opis zastosowanych procedur badawczych oraz wnioski.

W przypadku omawianego audytu wyodrębniono pięć kluczowych zagadnień badania:

- rozliczenie nabycia nowej spółki oraz grupy kapitałowej,

- rozpoznawanie przychodów ze sprzedaży,

- utrata wartości aktywów trwałych,

- odzyskiwalność aktywów z tytułu odroczonego podatku dochodowego,

- roszczenia, sprawy sporne i zobowiązania warunkowe.

Najważniejsze ustalenia dla każdego z wymienionych obszarów zostały zawarte w tabeli 3.

Na podstawie zaprezentowanego skrótu informacji ujawnianych przez audytora w zakresie kluczowych kwestii badania należy stwierdzić, że jest to faktycznie zupełna nowość w raportowaniu wyników audytu na zewnątrz. Dotychczas powyższe zagadnienia były oczywiście rozpoznawane w praktyce audytorskiej, ale stanowiły element wewnętrznej dokumentacji rewizyjnej. Teraz podstawowe elementy metodologii badania są ujawniane czytelnikowi, co z pewnością ułatwia interpretację wyników audytu. 
Tabela 3. Kluczowe zagadnienia w raporcie z badania sprawozdania skonsolidowanego spółki Cyfrowy Polsat SA za 2016 r.

\section{ROZLICZENIE NABYCIA SPÓŁKI X ORAZ JEJ GRUPY KAPITAŁOWEJ}

1. Przedstawienie zagadnienia:

W badanym okresie dokonano nabycia nowej spółki X oraz powiązanej z nią grupy kapitałowej. W wyniku tej transakcji badana grupa kapitałowa ujęła wartość firmy w wysokości $369 \mathrm{mln}$ zł.

2. Uzasadnienie zaliczenia do kluczowych kwestii badania:

Transakcja w dużym stopniu opiera się na szacunkach i wielu istotnych założeniach, w szczególności związanych z przyjętymi metodami wyceny poszczególnych aktywów i pasywów.

3. Wybrane procedury badania opisane $w$ raporcie biegłego:

- przegląd dokumentów transakcyjnych oraz badanie kwot zapłaconych w transakcji przejęcia,

- uzyskanie od audytora nabytej grupy kapitałowej raportów z badania oraz ich analiza,

- zrozumienie i ocena procesu identyfikacji nabytych aktywów i pasywów,

- analiza racjonalności istotnych założeń przyjętych przez zarząd przy alokacji ceny nabycia przez wewnętrznych specjalistów audytora w zakresie wycen,

- ocena zasadności przyjętych okresów amortyzacji dla ujętych aktywów.

4. Wnioski:

Na podstawie wykonanych procedur stwierdzono, że przyjęte przez zarząd założenia dotyczące wyceny związanej z powyższą transakcją są poprawne i jej skutki są prawidłowo przedstawione w sprawozdaniu finansowym.

1. Przedstawienie zagadnienia:

W roku badanym grupa osiągała przychody przede wszystkim ze sprzedaży detalicznej do klientów indywidualnych i biznesowych (głównie opłaty abonamentowe związane z pakietami telewizyjnymi) oraz sprzedaży hurtowej związanej z reklamą i sponsoringiem.

2. Uzasadnienie zaliczenia do kluczowych kwestii badania:

Specyfika tego typu sprzedaży detalicznej w dużym stopniu opiera się na wykorzystywaniu informatycznych systemów przetwarzania danych.

3. Wybrane procedury badania opisane $\mathrm{w}$ raporcie biegłego:

- zrozumienie i ocena środowiska kontroli wewnętrznych powiązanych z rejestracją przychodów ze sprzedaży,

- analiza wybranych systemów IT, w tym billingowych, stosowanych przez grupę,

- analiza istotnych kontraktów zawartych z podmiotami zewnętrznymi dotyczącymi sprzedaży,

- testy kontroli wewnętrznych w zakresie ujęcia i weryfikacji przychodów billingowych,

- testy szczegółowe polegające m.in. na uzgodnieniu wystawionych faktur sprzedaży, umów z klientami, zastosowanych stawek cenowych i płatności.

4. Wnioski:

Nie ujawniono istotnych kwestii, które wymagałyby korekty przychodów w sprawozdaniu

1. Przedstawienie zagadnienia:

UTRATA WARTOŚCI AKTYWÓW

W notach do sprawozdania finansowego podmiot badany zaprezentował ujawnienia dotyczące przeprowadzonego testu na utratę wartości, w tym wyniki testu, analizę jego wrażliwości i opis przyjętych założeń. Pozycja sprawozdawcza, której test dotyczy, to wartość firmy wynosząca 11 mld zł.

2. Uzasadnienie zaliczenia do kluczowych kwestii badania: 
Przeprowadzanie testów na utratę wartości związane jest z koniecznością przyjęcia szeregu założeń i dokonania osądów przez zarząd, szczególnie w zakresie przyjętej strategii działania grupy w kolejnych latach, planów finansowych i prognoz przepływów pieniężnych, kształtowania się wskaźników makroekonomicznych i rynkowych.

3. Wybrane procedury badania opisane w raporcie biegłego:

- zrozumienie i ocena procesu identyfikacji przesłanek utraty wartości aktywów oraz prawidłowości ich grupowania w ośrodki wypracowujące środki pieniężne,

- sprawdzenie poprawności matematycznej i spójności metodologicznej (z wykorzystaniem wewnętrznych specjalistów PwC w zakresie wycen) sporządzonego przez zarząd modelu wyceny na bazie zdyskontowanych przepływów pieniężnych,

- krytyczna ocena przyjętych w wycenie założeń z zakresu określenia wartości odzyskiwalnej aktywów trwałych,

- ocena przeprowadzonej przez zarząd analizy wrażliwości przyjętych założeń na wynik wyceny,

- ocena poprawności i kompletności ujawnień tego zagadnienia w sprawozdaniu finansowym.

4. Wnioski

Na podstawie przeprowadzonych procedur uznano założenia przyjęte przy wycenie przez zarząd za racjonalne i mające poparcie w dokumentacji

Przedstawienie zagadnienia:

Sprawozdanie finansowe prezentuje aktywa z tytułu odroczonego podatku dochodowego w wysokości ponad $232 \mathrm{mln}$ zł.

2. Uzasadnienie zaliczenia do kluczowych kwestii badania:

Kalkulacja tej pozycji bilansowej wiąże się z koniecznością dokonywania przez zarząd istotnych założeń i osądów księgowych. Dotyczą one w szczególności prawdopodobieństwa wystąpienia przyszłych zysków podlegających opodatkowaniu, od których będzie możliwe odliczenie strat podatkowych z lat ubiegłych.

3. Wybrane procedury badania opisane $\mathrm{w}$ raporcie biegłego:

- zrozumienie i identyfikacja procesu identyfikacji różnic przejściowych oraz kalkulacji aktywów z tytułu odroczonego podatku dochodowego,

- ocena skutków podatkowych istotnych transakcji i ich wpływu na rozpoznanie aktywów z tytułu odroczonego podatku dochodowego.

4. Wnioski:

Nie stwierdzono konieczności dokonywania istotnych korekt w sprawozdaniu

1. Przedstawienie zagadnienia:

$$
\text { ROSZCZENIA, SPRAWY SPORNE I ZOBOWIAZZANIA WARUNKOWE }
$$

Badana grupa zaprezentowała ujawnienia związane ze zobowiązaniami warunkowymi i sprawami spornymi, gdyż jest stroną postępowań sądowych i administracyjnych,

w tym przed organami regulacyjnymi i podatkowymi.

2. Uzasadnienie zaliczenia do kluczowych kwestii badania:

Ocena konieczności utworzenia rezerw oraz zakres ujawnień w tym obszarze wiąże się z nieodłącznym ryzykiem niepewności oraz koniecznością przyjęcia przez zarząd założeń i profesjonalnego osądu.

3. Wybrane procedury badania opisane w raporcie biegłego:

- zrozumienie i ocena środowiska kontroli wewnetrznych dotyczacych identyfikacji, ujęcia i wyceny rezerw na sprawy sporne oraz zobowiązań warunkowych,

- analiza odpowiedzi uzyskanych od doradców prawnych badanego podmiotu prowadzących ww. sprawy sądowe, podatkowe i administracyjne, opisujących ich status oraz możliwe rozstrzygnięcie,

- ocena założeń i szacunków zarządu spółki badanej w odniesieniu do wysokości utworzonych rezerw na zobowiązania i ujawnionych zobowiązań warunkowych,

- analiza protokołów z posiedzeń organów stanowiących (zarządu, rady nadzorczej, zgromadzeń właścicieli) istotnych spółek wchodzących w skład grupy.

4. Wnioski:

W świetle dostarczonych dowodów uznano, że osądy i szacunki dokonane przez zarząd w tych kwestiach są uzasadnione

Źródło: opracowanie własne na podstawie Sprawozdania niezależnego biegłego rewidenta sporządzonego zgodnie z Międzynarodowymi Standardami Badania z audytu sprawozdania skonsolidowanego Grupy Cyfrowy Polsat SA za 2016 r. 


\section{Zakończenie}

Zaprezentowana analiza zmian legislacyjnych w zakresie raportowania przez biegłego rewidenta wyników audytu powiązana z przykładami ich praktycznego zastosowania wyraźnie wskazuje, że obecnie czytelnik pozyska więcej informacji nie tylko na temat badanej jednostki, ale przede wszystkim warsztatu pracy audytorów. Z pewnością wpłynie to pozytywnie na efektywność podejmowanych decyzji inwestycyjnych. Zwraca to również uwagę na istotę audytu, która niestety nadal nie do końca jest poprawnie rozumiana przez środowisko biznesowe.

Należy przy tym wspomnieć, że nowy styl raportowania będzie wymuszał na biegłych pełne wdrożenie procedur badania opartych na szacowaniu ryzyka i projekcji skutecznych procedur weryfikacji jego poziomu. Wydaje się również, że mimo wdrożenia obowiązku przygotowywania wyłącznie jednego dokumentu skierowanego do inwestorów (a nie jak dotychczas dwóch) wcale nie będzie łatwiej go sporządzić. Wnioski z audytu i sposób ich prezentacji będą musiały mieć solidne podstawy merytoryczne.

Wyniki przedstawionych badań wskazały, że część polskich audytorów już wcześniej przygotowywała się do tych zmian i fakultatywnie wdrażała nowe zapisy w opiniach, śledząc na bieżąco zmiany przepisów prawnych.

\section{Literatura}

Dyrektywa PE i Rady nr 2014/56/UE z 16 kwietnia 2014 r. zmieniająca dyrektywę 2006/43/WE w sprawie ustawowych badań rocznych sprawozdań finansowych i skonsolidowanych sprawozdań finansowych.

EY, EU Audit Legislation. Understanding the Legislation and How It Will Affect You, October 2014.

IAASB, New and Revised Auditor Reporting Standards and Related Conforming Amendments, January 2015.

IAASB, The New Auditor's Report, March 2015.

ISA 700 Forming an Opinion and Reporting on Financial Statements, IAASB.

ISA 701 Communicating Key Audit Matters in the Independent Auditor's Report, IAASB.

KPMG, Reforma rynku audytorskiego w Unii Europejskiej-co należy wiedzieć, sierpień 2015.

Opinie i raporty z badania skonsolidowanych sprawozdań finansowych spółek WIG-20 za lata 2013-2016 .

PwC, EU Audit Reform - Audit Firm Reporting, February 2015.

Rozporządzenie PE i Rady nr 537/2014 z 16 kwietnia 2014 r. w sprawie szczegółowych wymogów dotyczących ustawowych badań sprawozdań finansowych jednostek interesu publicznego.

„Rzeczpospolita” z 30.12.2015, Komunikacja audytora będzie lepsza.

„Rzeczpospolita” z 20.02.2015, Audytor uchyla drzwi. 